\title{
MEGALOBLASTIC ANAEMIA OF INFANCY IN JAMAICA
}

\author{
BY \\ J. E. MACIVER and E. H. BACK \\ From the Departments of Pathology and Medicine, University College of the West Indies, Jamaica
}

(RECEIVED FOR PUBLICATION MAY 21, 1959)

Anaemia in infancy responding specifically to haemopoietic factors present in liver is not common. Between the years 1946 and 1953 a considerable number of cases was reported from the United States of America (Zuelzer and Ogden, 1946) and Italy (Amato, 1946; Pecorella, Burgio and Aversa, 1947). The literature up to 1953 is fully reviewed by Zuelzer and Rutzky (1953). Since that time reports have been rather rare (Freire, 1954; Mouriquand, 1954; Elizavéta, 1955; Morice, Gurzmán and Costa, 1955; Nelson and Creery, 1955; Amato and Di Gruttola, 1956; Gatto, 1957).

Much of the evidence suggests that megaloblastic anaemia of infancy is largely nutritional in origin, and it might therefore be expected that the disease would be common in those parts of the world where malnutrition is still rife. Protein malnutrition is widespread in Africa, the Far East, Mexico, South America and the West Indies (Trowell, Davies and Dean, 1954). Some degree of anaemia is usual in this disease, although an analysis of published material suggests that it is not as a rule severe in uncomplicated cases, since the haemoglobin level averages about $9.0 \mathrm{~g} . \%$ (Table 1 ). The anaemia is

TABLE 1

AVERAGE HAEMOGLOBIN LEVELS IN KWASHIORKOR

\begin{tabular}{|c|c|c|c|}
\hline Author & Area & $\begin{array}{l}\text { Cases } \\
\text { (no.) }\end{array}$ & $\underset{(\mathrm{g} . \%)}{\operatorname{Mean} \mathrm{Hb}}$ \\
\hline Altmann and Murray (1948) & Johannesburg & 32 & $10 \cdot 2$ \\
\hline $\begin{array}{r}\text { Walt, Wills and Nightingale } \\
(1950)\end{array}$ & Durban & 36 & $10 \cdot 1$ \\
\hline Van der Sar & Curaçao & 33 & $9 \cdot 3$ \\
\hline Trowell and Davies & Uganda & 44 & $8 \cdot 5$ \\
\hline $\begin{array}{l}\text { Gómez, Santaella, Galván, } \\
\text { Cravioto and Frenk(1954) }\end{array}$ & Mexico & 51 & $9 \cdot 3$ \\
\hline Netrasiri and Netrasiri & Thailand & 48 & $8 \cdot 7$ \\
\hline Woodruff & Nigeria & 6 & $8 \cdot 2$ \\
\hline Poey Seng Hin & Djakarta & 138 & $8 \cdot 9$ \\
\hline
\end{tabular}

most commonly normocytic, although it may be microcytic or macrocytic (Altmann and Murray, 1948). It responds slowly to a protein-rich diet, and the response to liver, vitamin $\mathbf{B}_{12}$ and folic acid has been described as 'poor, indefinite and erratic' (Trowell, 1949). The anaemia is commonly ascribed to protein deficiency associated with liver disease (Woodruff, 1955), although Gómez, Santaella, Galván, Cravioto and Frenk (1954) suggest that it can usually be attributed to an increase in plasma volume.

There have been few bone marrow studies in protein malnutrition. Trowell (1949) states that although at one time he thought that erythropoiesis was commonly megaloblastic, later he changed his opinion and now considers that erythropoiesis is usually macronormoblastic. Lambrecht and Holemans (1952) found some degree of erythroid hypoplasia but no megaloblasts in 24 cases. Woodruff (1955) found a macronormoblastic marrow in six cases. Altmann and Murray (1948) reported megaloblasts and giant stab cells in the marrows of a few of their cases, and Adams (1954) in Durban, South Africa, found megaloblasts in two out of 21 cases and giant stab cells and intermediate megaloblasts' in another six cases. Van der Sar (1951) reported one case with megaloblastic erythropoiesis which responded to folic acid. Kho Lien-Keng, Poesponegoro and Poey Seng Hin (1957) studied the bone marrow in 50 cases in Djakarta and reported occasional megaloblasts in six cases and giant stab cells, vacuolated granulocytes or hypersegmented neutrophils in another 26 cases. There was usually erythroid hypoplasia and the response to specific treatment was on the whole poor. Walt, Wills and Nightingale (1950) found no megaloblasts in 36 cases in Durban, but six years later they were able to report 42 cases of megaloblastic anaemia of infancy of whom just over half were also suffering from kwashiorkor (Walt, Holman and Hendrickse, 1956). The following year they described another 18 cases (Walt, Holman and Naidoo, 1957). In Sicily a condition has been described 
which resembles kwashiorkor very closely (Gerbasi and Burgio, 1955). It usually affects children under 2 years of age who suffer from diarrhoea, often of long standing, and skin changes, dryness of the hair, oedema and hepatomegaly. The liver often shows a severe fatty change, the serum proteins are low and anaemia is common and sometimes severe. Bone marrow studies showed megaloblasts in 10 cases and giant myeloid forms in 20 cases. The typical white cell changes of megaloblastic anaemia of infancy are well illustrated in their paper.

The purpose of this communication is to report 50 cases of megaloblastic anaemia of infancy seen between May, 1956, and November, 1958, and to emphasize that the disease is a common one in Jamaica.

\section{Methods}

Standard haematological methods were used (Whitby and Britton, 1957). In vitro sickling tests were carried out using a $2 \%$ solution of sodium metabisulphite (Daland and Castle, 1948).

Bone marrow was aspirated under local anaesthesia, using an Osgood (16 gauge) needle. The site of puncture selected was the upper end of the tibia about 2 in. below the tibial tuberosity. The marrow films were stained by both Leishman's method and the May-Grünwald-Giemsa technique. A portion of the aspirated material was allowed to clot in the syringe, and the specimen so obtained was fixed and sectioned histologically as described by Mertens (1945). The sections were stained with haematoxylin and eosin, and for iron by the prussian blue technique of Perls. All the sections were stained for iron simultaneously to minimize technical errors.

\section{Results}

The age distribution follows closely the pattern of kwashiorkor (Fig. 1) and, of the 50 cases, 32 were boys and 18 girls. Fever, vomiting and diarrhoea were the most common complaints and upper respiratory tract infections were frequent. On examination the most striking finding was that all the children were underweight and many severely so. This is represented graphically in Fig. 2 where the children's admission weights are compared with standard curves based on studies of child health and development made by the Department of Maternal and Child Health, Harvard School of Public Health (Nelson, 1950). In only one instance (Case 12) did the admission weight exceed the third percentile, but even in this case the figure was well below the mean (50th percentile) in the Boston series. Other stigmata of malnutrition were also found; some degree of oedema was present in $\mathbf{3 0}$ children, dyspigmentation of the skin was seen in 14 cases, and hair changes were found in 35 cases. The liver was readily palpable in $\mathbf{4 4}$ cases and grossly enlarged in seven of these. The spleen was palpable in five instances, but three of these cases also had sickle cell anaemia. Two other cases of sickle cell anaemia were seen and these five infants with sickle cell anaemia and associated megaloblastic anaemia are reported elsewhere (MacIver and Went, 1960). Extreme pallor of the palms of the hands, soles of the feet and mucous membranes was usually present. In summary all the infants in this series were suffering from malnutrition, which ranged clinically from

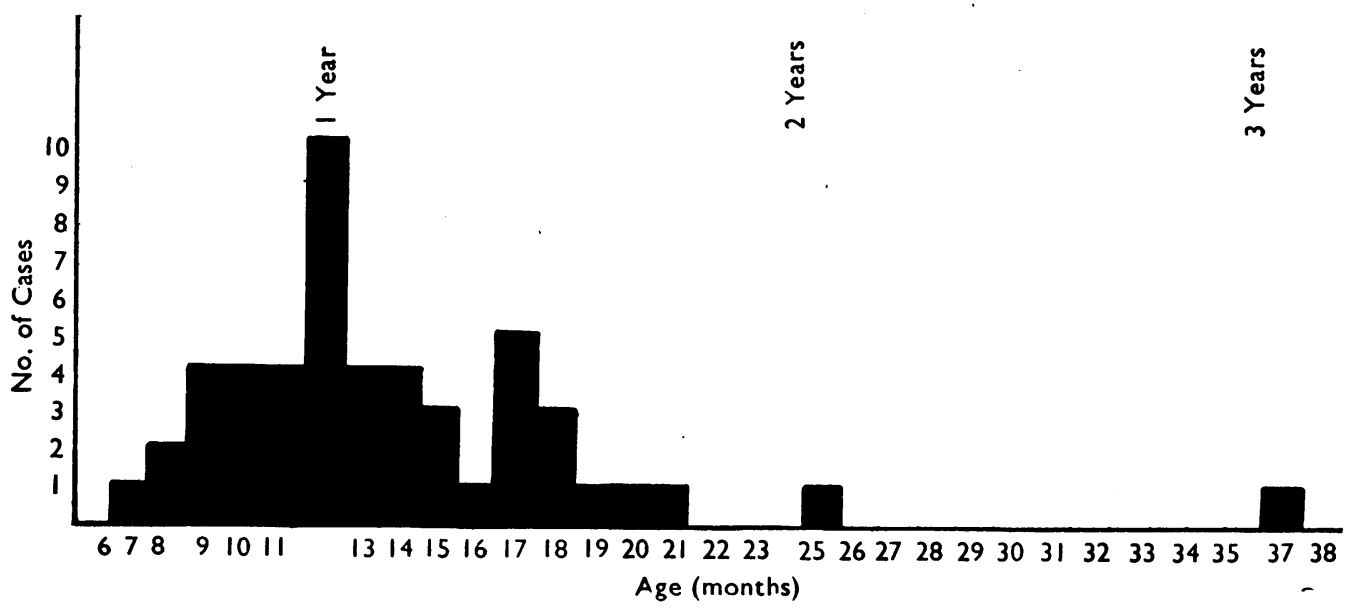

FIG. 1.-Age distribution of 50 cases of megaloblastic anaemia in infancy 


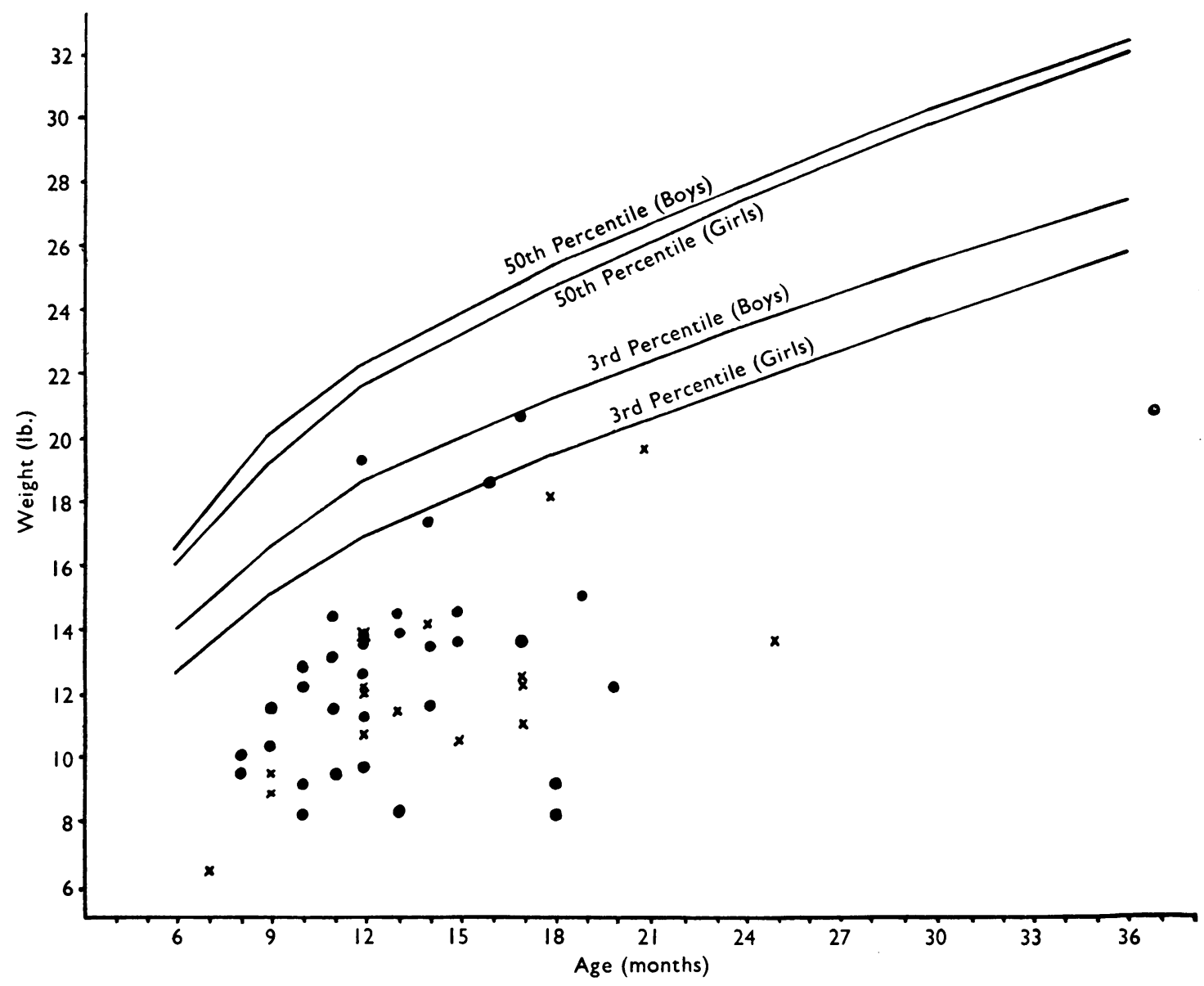

Fig. 2.-Admission weights of 50 cases of megaloblastic anaemia of infancy arranged by age as compared with standard curves for third and fiftieth percentiles prepared by the Department of Maternal and Child Health, Harvard School of Public Health $\bullet$ boys $\times$ girls.

classical kwashiorkor in a few cases to a more marasmic picture in the majority.

The haemoglobin levels on admission ranged from $1 \cdot 4$ to $12 \cdot 2 \mathrm{~g} . \%$ but the great majority were very low (average $5 \cdot 4 \mathrm{~g} . \%$ ). The few cases with high haemoglobin levels on admission developed anaemia in the course of treatment for malnutrition and bone marrow examination was rarely performed until the haemoglobin level had fallen to $7.0 \mathrm{~g} . \%$ or less. The anaemia was usually normocytic and normochromic in type. Only occasionally was it definitely macrocytic (e.g. Case 48), but sometimes it was hypochromic. The reticulocyte count on admission was normally low, often below $1 \%$ (average $2 \cdot 3 \%$ ). The serum albumin level was usually low, ranging from 1.2 g. $\%$ to 4.4 g. $\%$ (average 2.5 g. $\%$ ). Stool cultures were performed in the great majority of cases: $S$. typhimurium was isolated in three instances (Cases 8, 9 and 34), S. St. Paul was found once (Case 14), pathogenic Esch. coli was isolated in five cases (type 0111 in Cases 3 and 29, type 055 in Case 8 and type 026 in Cases 14 and 42) and Sh. sonnei was found in one instance (Case 43). Mantoux and V.D.R.L. tests were negative in all cases examined, and the stools were examined routinely for hookworm and other parasites but were negative in every case. Gastric acidity was tested in five cases following the injection of histamine. In two (Cases 45 and 47) some free acid was found, whereas in the other instances (Cases 43, 46 and 50) there was no free acid. Faecal fats were estimated in three cases. In two, normal values were obtained $(3 \mathrm{~g}$. per $100 \mathrm{~g}$. dry faeces in Case 46 and $2 \cdot 6 \mathrm{~g}$. per $100 \mathrm{~g}$. dry faeces in Case 43). In the other infant (Case 34) a 
raised value of $36 \mathrm{~g}$. per $100 \mathrm{~g}$. dry faeces was found, but on follow-up the percentage of fat fell to 14 and then to $6.5 \mathrm{~g} . \%$ as the child improved clinically. The bone marrow was studied in every case, although in one infant (Case 49) the aspiration was performed 64 hours, and in another (Case 50) 16 hours after the start of oral folic acid therapy. In the majority of instances the marrow was of greatly increased cellularity, although in a few it was hypocellular and fatty. The mean myeloid/erythroid ratio in the whole series was 1.9 to 1 , which contrasts strikingly with the findings of Kho Lien-Keng et al. (1957) in Indonesia, who found an average myeloid/ erythroid ratio of $13 \cdot 4$ to 1 .

\section{Bone Marrow Morphology}

(1) Erythropoiesis. In many instances the picture was indistinguishable from that seen in pernicious anaemia in relapse, and erythropoiesis was frankly megaloblastic (Fig. 3). Not infrequently, however, although megaloblasts were present in sufficient numbers to make the diagnosis beyond dispute, the majority of the erythroblasts were intermediate in type in the sense used by Downey (1952). These are the 'intermediate megaloblasts' of Dacie and White (1949). In such bone marrows erythroblasts could be seen in every stage of abnormality from classical megaloblasts on the one hand, through a variety of intermediate stages to typical normoblasts. In some marrows (e.g., Cases 8, 27, 30 and 31) no classical megaloblasts were seen at all, and although the erythroblasts were still abnormal it was not possible to describe erythropoiesis as other than normoblastic. In such marrows it was still possible to recognize a specific and diagnostic abnormality in the myeloid cells.

(2) Leucopoiesis. The granulocyte precursors showed constant qualitative changes which were no less characteristic than those of the erythroblasts. They were usually large and of a bizarre shape. Often they were clearly immature, perhaps premyelocytes or myelocytes, and yet the nucleus had undergone lobulation, indentation and even segmentation. Precise classification was often difficult. Giant metamyelocytes and stab cells were the most easily recognized abnormality and were identical with those seen in pernicious anaemia (Fig. 4). Striking vacuolation of the abnormal myeloid cells was often present (Fig. 5). We agree with Zuelzer and Rutzky (1953) that so far as megaloblastic anaemia of infancy is concerned these white cell changes are pathognomonic. They were seen in every marrow in the series, and sometimes they were unmistakably abnormal even when no typical megaloblasts could be found. In such cases a therapeutic test with folic acid produced a characteristic reticulocyte response and a sustained haematological improvement. There is no doubt that these changes in the granulocytes provide a sensitive and easily visualized indicator of the early stages of megaloblastic anaemia before the characteristic changes in the erythroblasts have become apparent. We have never seen these white cell changes in iron deficiency anaemia, as reported by Davidson (1952) and Lehmann (1955).

Pathology. Six infants out of the series of 50 died and necropsies were carried out on all of them. In general the findings were those which are typically seen in protein malnutrition in children under 2 years of age in Jamaica (Jelliffe, Bras and Stuart, 1954; Bras, Waterlow and DePass, 1956). An additional finding which was of interest was that extramedullary erythropoiesis was seen in the liver (Fig. 6) in three Cases $(3,28,43)$. In two others (Cases 4 and 44) a severe chronic fatty change was present, and in Case 6 an acute fatty change was noted. The immediate cause of death was frequently anaemia and bronchopneumonia.

Liver biopsies were carried out on 12 other infants, and extramedullary erythropoiesis was noted in seven of the 10 biopsy specimens which were sectioned histologically (Cases 13, 15, 16, 21, 22, 23 and 36). A severe chronic fatty change was seen in Cases 16, 23, 29 and 38.

We regard the finding of extramedullary erythropoiesis in the liver as a very characteristic feature of the disease since it has not been observed in several hundred necropsy and liver biopsy specimens from children with malnutrition in Jamaica, unless there was an associated megaloblastic anaemia. It is not, however, always present, and may be difficult to see or completely absent if the liver is very fatty.

\section{Response to Treatment}

Of the 50 cases in the series 45 were treated with folic acid and five received vitamin $B_{12}$. Six of the folic acid-treated cases died. The response to treatment is summarized in Table 2.

Folic Acid Therapy. The response to oral folic acid ( $5 \mathrm{mg}$. b.d.) in the 39 patients who recovered was uniformly excellent (Fig. 7). Within one or two days of starting treatment a striking clinical improvement was frequently noted. The increase in appetite and diminution of apathy were very marked and often preceded the reticulocyte response. Vomiting and diarrhoea, which had sometimes persisted for several weeks, were usually brought under control within a few days. A maximum reticulocyte response was 


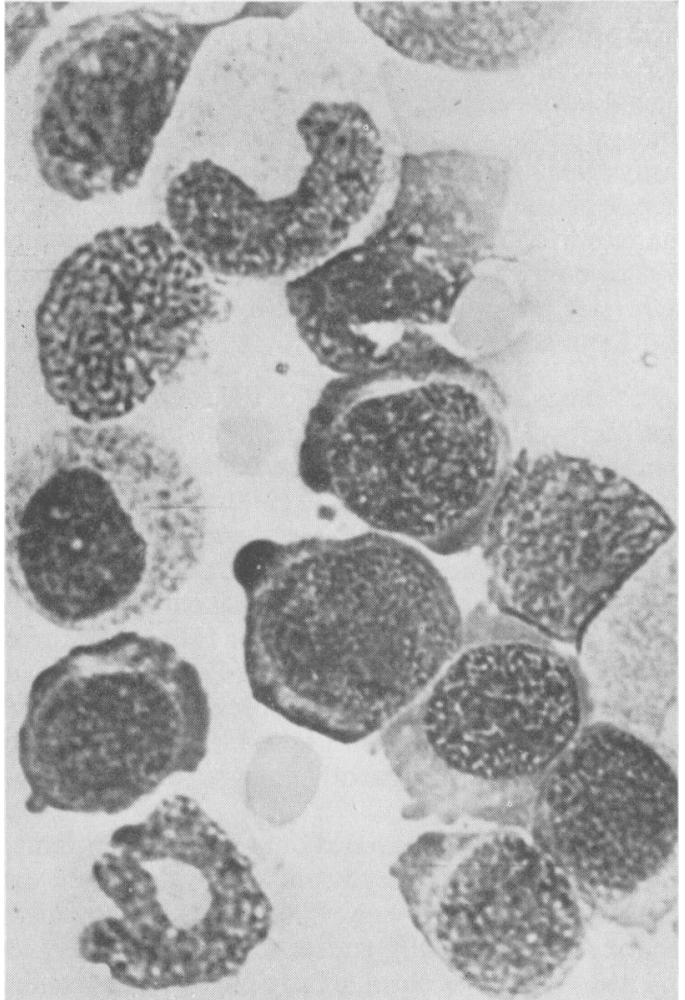

FIG. 3.

FIG. 3.-Bone marrow from Case 13. $(\times 1200)$

Fig. 4.-Bone marrow from Case 13 showing giant metamyelocytes and giant stab cells. $(\times 1200)$

Fig. 5.-Bone marrow from Case 6 showing vacuolated granulocytes. $(\times 1200)$

FIG. 6.-Necropsy section of liver from Case 3 showing extensive extramedullary erythropoiesis. $(\times 225)$

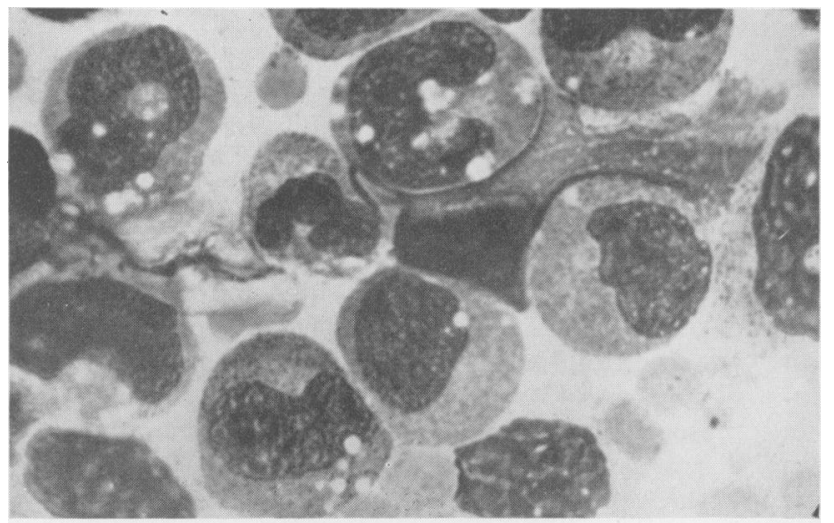

FIG. 5.

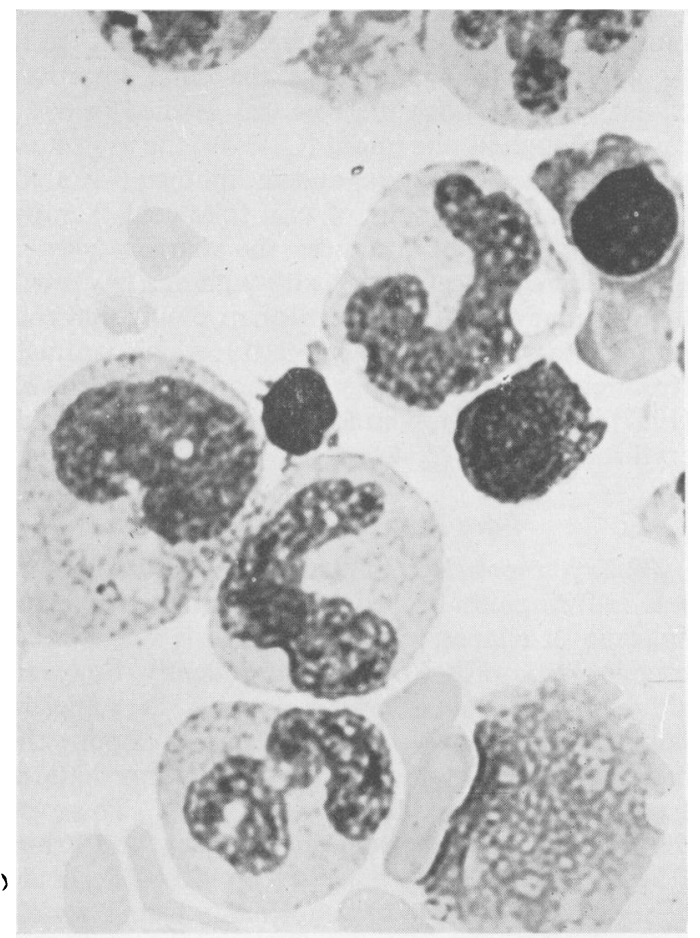

FIG. 4.

8 용

(2)

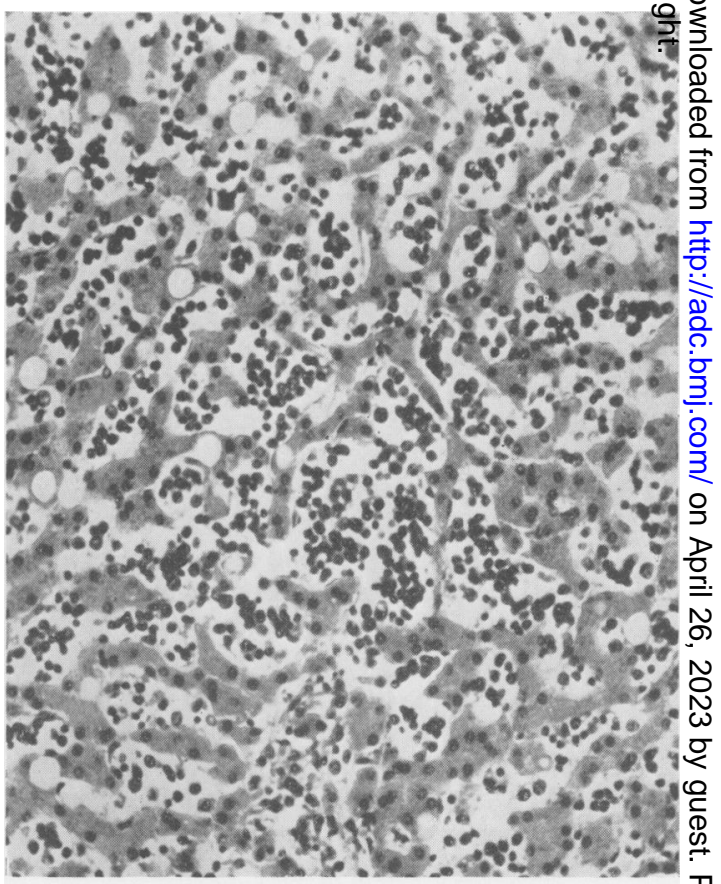

FIG. 6.

.


TABLE 2

RESPONSE TO TREATMENT (10 MG. FOLIC ACID DAILY, UNLESS OTHERWISE SPECIFIED)

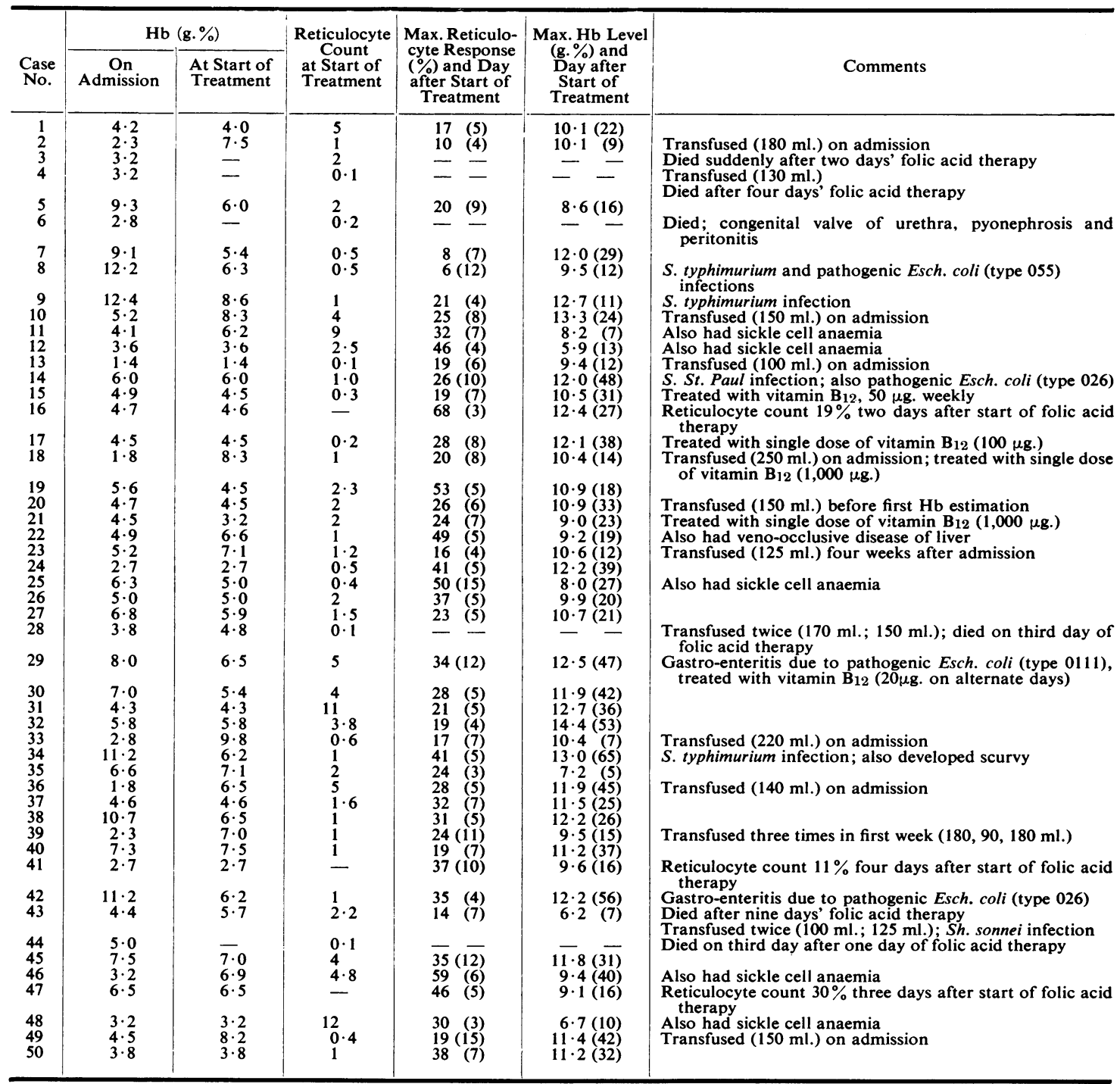

sometimes seen in as short a time as three days and occasionally, particularly in the presence of severe infection, took as long as 15 days (mean six days). The rise in haemoglobin level after therapy was usually quite rapid, and in the 21 cases who received no blood transfusions the rate of increase in haemoglobin ranged from $0.08 \mathrm{~g}$. per day to $0.37 \mathrm{~g}$. per day (mean $0 \cdot 2 \mathrm{~g}$. per day).

Iron Therapy. Oral iron therapy was usually also required to achieve a sustained improvement, and in fact some cases were demonstrably iron-deficient from the start as judged by a low mean corpuscular haemoglobin concentration, or more reliably by the absence of stainable iron in the bone marrow. Of the 31 cases in which the marrow was stained for iron, a positive reaction was obtained in 19, although in four of these only a trace of iron was seen. In seven cases ample iron was present $(2,6,25,34,41$, 43 and 47) but of these only Cases 6 and 47 had received no treatment before the marrow biopsy; Cases 2, 25 and 43 had been given blood transfusions, 


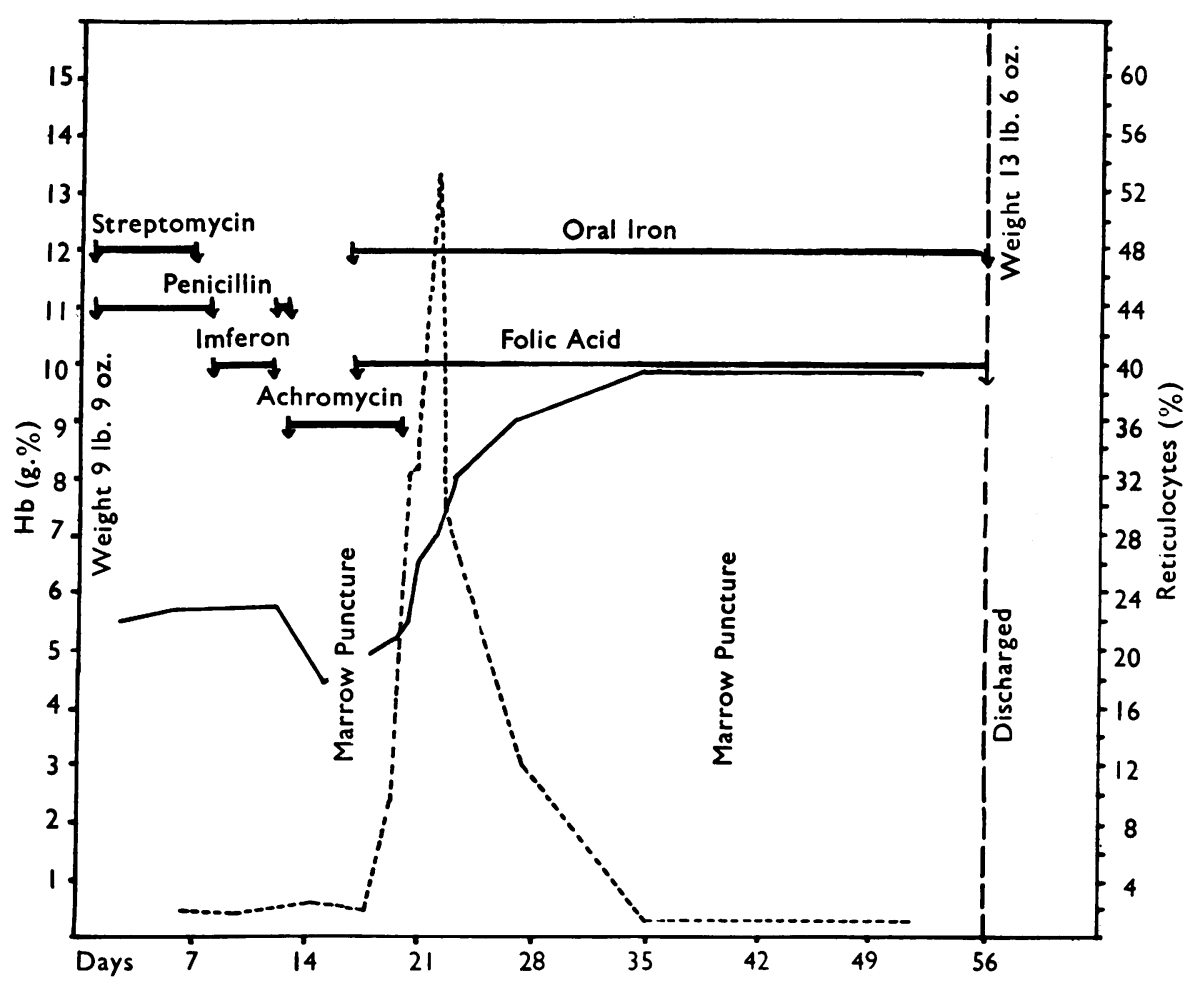

Fig. 7.-Chart of Case 19, aged 9 months, showing typical response to oral folic acid therapy.

Hb -..- reticulocytes

Case 41 had had two days of intramuscular iron and Case 34 had been on oral iron therapy for over three weeks. However, it is noteworthy that in no case was haematological improvement seen on iron therapy alone, and in fact in several instances the infant had been on iron therapy for some time before the marrow was examined, but in spite of that had continued to go downhill. Case 7 received $5 \mathrm{ml}$. of Imferon but nevertheless the haemoglobin level fell from $9.1 \mathrm{~g} . \%$ on admission to $5.4 \mathrm{~g} . \%$ in 38 days. Case 9 was on oral iron whilst the haemoglobin level fell $2.4 \mathrm{~g} . \%$, and Case 34 had been on oral iron therapy for 23 days when the marrow was examined, and during this period the haemoglobin level had fallen $2 \cdot 1 \mathrm{~g} . \%$.

Vitamin $\mathbf{B}_{12}$ Therapy. All five cases receiving intramuscular vitamin $\mathbf{B}_{12}$ had a completely satisfactory haematological and clinical response. The dosage varied but was usually on the high side. Case 15 received $50 \mu \mathrm{g}$. a week for eight weeks, Case 29 was given $20 \mu \mathrm{g}$. on alternate days up to a total of $220 \mu \mathrm{g}$. and in the other three cases $(17,18$ and 21) a single injection of $1000 \mu \mathrm{g}$. was given.

Antibiotics. A high proportion of the infants were febrile on admission, and many had bronchopneumonia or gastro-enteritis. As a consequence, penicillin and achromycin were not uncommonly given during the first weeks after admission. Since nutritional megaloblastic anaemia in adults sometimes responds to penicillin (Foy, Kondi and Manson-Bahr, 1955), a response in infants might be anticipated. However, in no case was a response observed which could be ascribed to the antibiotic treatment, and in a number of instances the bone marrow aspiration was performed after prolonged use of antibiotics and erythropoiesis was none the less megaloblastic.

\section{Discussion}

Megaloblastic anaemia of infancy is a common condition in Jamaica and in $19576.3 \%$ of all admissions to the paediatric ward of the University College Hospital suffered from the disease. It is clearly a deficiency state, but the origin of the deficiency and what factor or factors are concerned in this deficiency is much less obvious. The ultimate biochemical defect may be of folic acid or its analogues, vitamin $\mathbf{B}_{12}$, or other factors as yet unknown, and the deficiency need not necessarily be the 
same in each case. The fact that all reported cases have responded to folic acid, as have all the surviving cases treated with this substance in the present series, does not prove that the deficiency is one of folic acid. The response to vitamin $\mathrm{B}_{12}$ in megaloblastic anaemia of infancy has been more variable; all the children treated with it in the present series responded well, although the dosage in some cases was very high and, according to Frazer (1958), all megaloblastic anaemias will respond to vitamin $B_{12}$ provided the dosage is high enough. Other workers have reported satisfactory responses (McPherson, Jonsson and Rundles, 1949; Sturgeon and Carpenter, 1950; Zuelzer and Rutzky, 1953) although in some cases the response has been poor (Luhby and Wheeler, 1949; Zuelzer and Rutzky, 1953).

One of the most remarkable things about the history of megaloblastic anaemia of infancy is the almost meteoric rise and fall in the incidence of the condition in the United States. The flood of cases reported in that country between 1946 and 1953 may in part have been due to a 'high index of suspicion', but the virtual disappearance of the disease since 1953 is more difficult to explain. Considerable light was thrown on the aetiology of megaloblastic anaemia in infancy by the work of May and his associates, who undertook a series of experimental investigations on monkeys and showed that a megaloblastic anaemia could readily be induced in these animals by a diet of milk, which has a low content of folic acid, from which ascorbic acid has been excluded (May, Nelson and Salmon, 1949; May, Nelson, Lowe and Salmon, 1950; May, Sundberg and Schaar, 1950; May, Sundberg, Schaar, Lowe and Salmon, 1951; May, Stewart, Hamilton and Salmon, 1952; May, Hamilton and Stewart, 1953; Sundberg, Schaar and May, 1952). In considering the possible causes of folic acid and vitamin $\mathrm{B}_{12}$ deficiency they concluded that 'a chronic deficiency of ascorbic acid leads to a deficiency of folic acid or some difficulty in the metabolism of folic acid or related compounds which results in a megaloblastic pattern in the marrow.' As evidence for this view they cited the high frequency of scurvy $(25 \%)$ in the case reports of Zuelzer and Ogden (1946) and Aldrich and Nelson (1947).

As a result of the work of May and his associates, the manufacturers introduced large quantities of ascorbic acid ( $50 \mathrm{mg}$. per reconstituted quart) into milk formulas which had previously been associated with a rather high incidence of megaloblastic anaemia of infancy (Luhby and Wheeler, 1949), and it is probable that the virtual disappearance of the disease in the United States may, in part at least, be ascribed to this fact. In this connexion it is of interest that in Zuelzer's last published series of cases (Zuelzer and Rutzky, 1953) milk foods, which had been modified by the sole addition of ascorbic acid, disappeared from the history of infants with megaloblastic anaemia, whereas an unmodified brand persisted.

The importance of ascorbic acid deficiency in the aetiology of the disease in the present series is difficult to evaluate. In only one instance (Case 34) was frank scurvy noted and the deficiency became manifest after the child had been in hospital for 78 days. The infant was malnourished on admission but was not particularly anaemic, even taking into account the dehydration which was present. He had severe gastro-enteritis and $S$. typhimurium was isolated from the stools. Despite courses of achromycin and chloramphenicol the diarrhoea persisted and the Salmonella was again found. The child was on a milk diet with the addition of small quantities of orange juice during this period, but the haemoglobin fell steadily from $11 \cdot 2 \mathrm{~g} . \%$ to $6 \cdot 4 \mathrm{~g} . \%$ after 55 days (Fig. 8). A bone marrow examination at this time showed megaloblastic erythropoiesis, and folic acid was given. A good reticulocytosis and some rise in haemoglobin followed, but soon afterwards the haemoglobin level began to fall again. Clinical evidence of scurvy then appeared and treatment with ascorbic acid (the folic acid was still continued) produced a second reticulocyte response of $20 \%$ and a rapid rise in haemoglobin level. In this case there can be no doubt about the importance of ascorbic acid in the proper utilization of folic acid, but, since scurvy is very rarely seen in Jamaica, it is difficult to believe that a deficiency of ascorbic acid can be of aetiological significance in the majority of cases in this series.

There is little doubt of the important part played by infection in the causation of the disease. May et al. (1952) were able to produce megaloblastic anaemia in monkeys on a milk diet with adequate amounts of ascorbic acid by inducing turpentine abscesses. It is probable that infection increases the requirements for ascorbic acid. In the present series infections were extremely frequent. A history of recent upper respiratory tract infections or chest colds was elicited in 26 cases, and gastro-intestinal infections were common. Vomiting had occurred in 37 cases, and diarrhoea in 29 . As mentioned earlier, specific pathogens were isolated from the stools in several instances, and the importance of gastro-intestinal infections in the aetiology of megaloblastic anaemia is well illustrated by the following case.

Case 9. This 9-month-old infant was admitted with a history of vomiting after feeds for one week and diarrhoea 


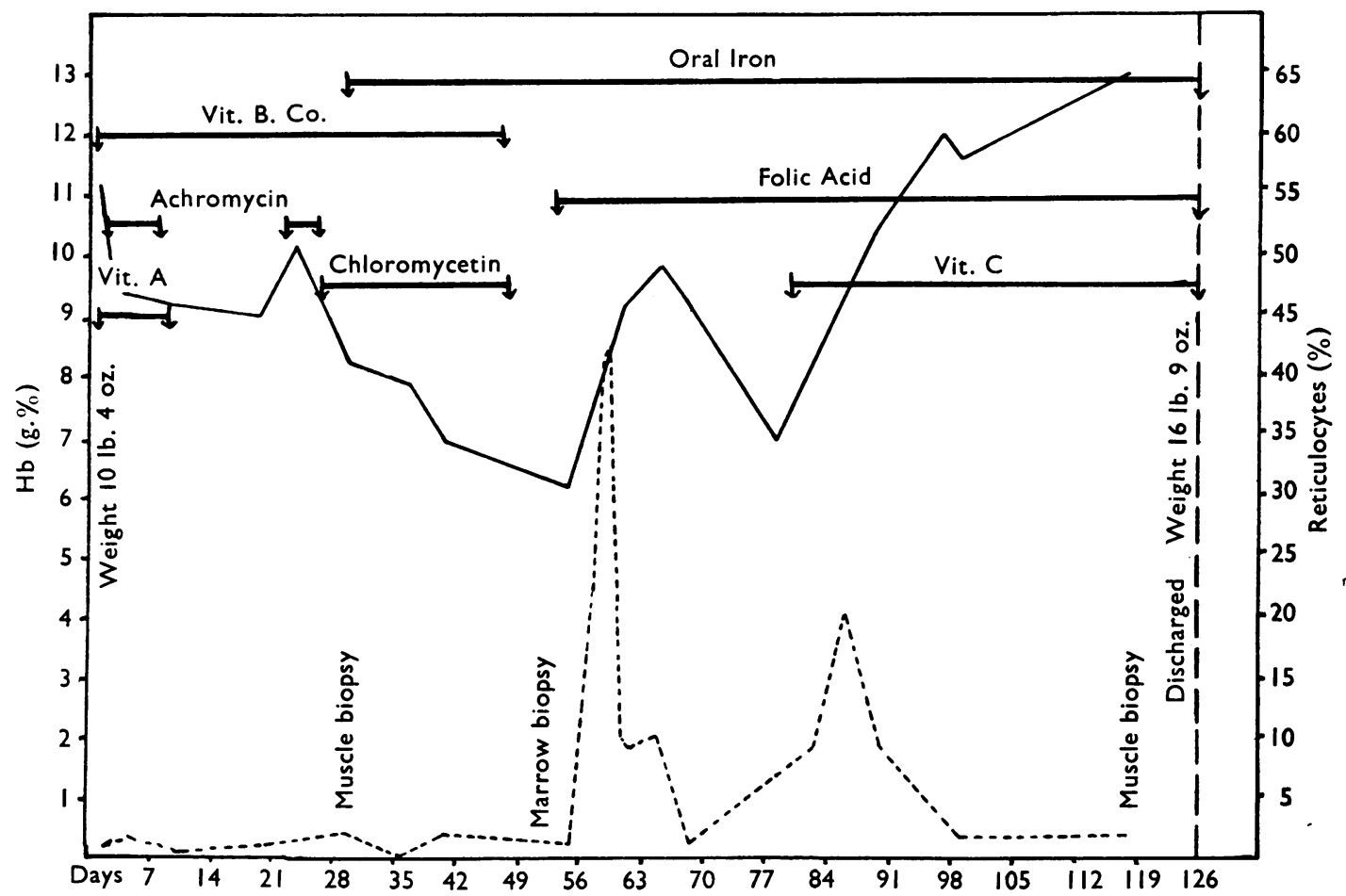

FIG. 8.-Chart of Case 34, aged 8 months, showing fall in haemoglobin level associated with $S$. typhimurium infection, response to folic acid and second response to ascorbic acid (see text). $\mathrm{Hb} \ldots$ reticulocytes

for three days. His nutritional state was moderate. $S$. typhimurium was isolated from the stools and despite a course of chloramphenicol the same organism was found again two weeks later. During the course of the first four weeks the haemoglobin level fell from $12.4 \mathrm{~g} . \%$ to 6.7 g. $\%$ (Fig. 9) and, despite treatment with penicillin and streptomycin, he had continual fever. A blood transfusion was given but the haemoglobin level fell again rapidly. On the forty-sixth day the bone marrow was examined and found to be megaloblastic. Treatment with folic acid produced a dramatic result both clinically and haematologically for not only was there a good reticulocyte response and haemoglobin rise, but the fever settled almost immediately and did not recur.

A similar rapid fall in haemoglobin level in infants with gastro-enteritis was observed in Cases 8, 34 and 42.

The mechanism by which gastro-intestinal infections predispose to the development of a megaloblastic anaemia is probably rather complex. In the first place there is the factor of the infection itself, which has already been discussed. Secondly, anorexia and vomiting are frequently associated so that the intake of haemopoietic factors is reduced.
Thirdly, the absorption of these haemopoietic factors may be impaired as a result of persistent diarrhoea. Fourthly, the abnormal bacterial flora in the intestine associated with the infection may lead either to an increased bacterial utilization of these factors or to a reduced synthesis of them.

However important infection and ascorbic acid deficiency may be in the causation of megaloblastic anaemia of infancy, there can be little doubt that the main factor responsible in our series is a dietary deficiency of essential haemopoietic substances. All the infants in the series were underweight, and many were severely so. In addition the features of protein malnutrition were often present. In Table 3 are summarized the diets of the infants in this series, and they are clearly grossly inadequate. Milk, which is the chief staple of an infant's diet during the first year of life, has a low folic acid content, and the heating processes, such as those involved in the canning and powdering of milk, further reduce this small amount of folic acid (Luhby and Wheeler, 1949). Only a few of the infants received any fresh milk and the majority were given only very small 


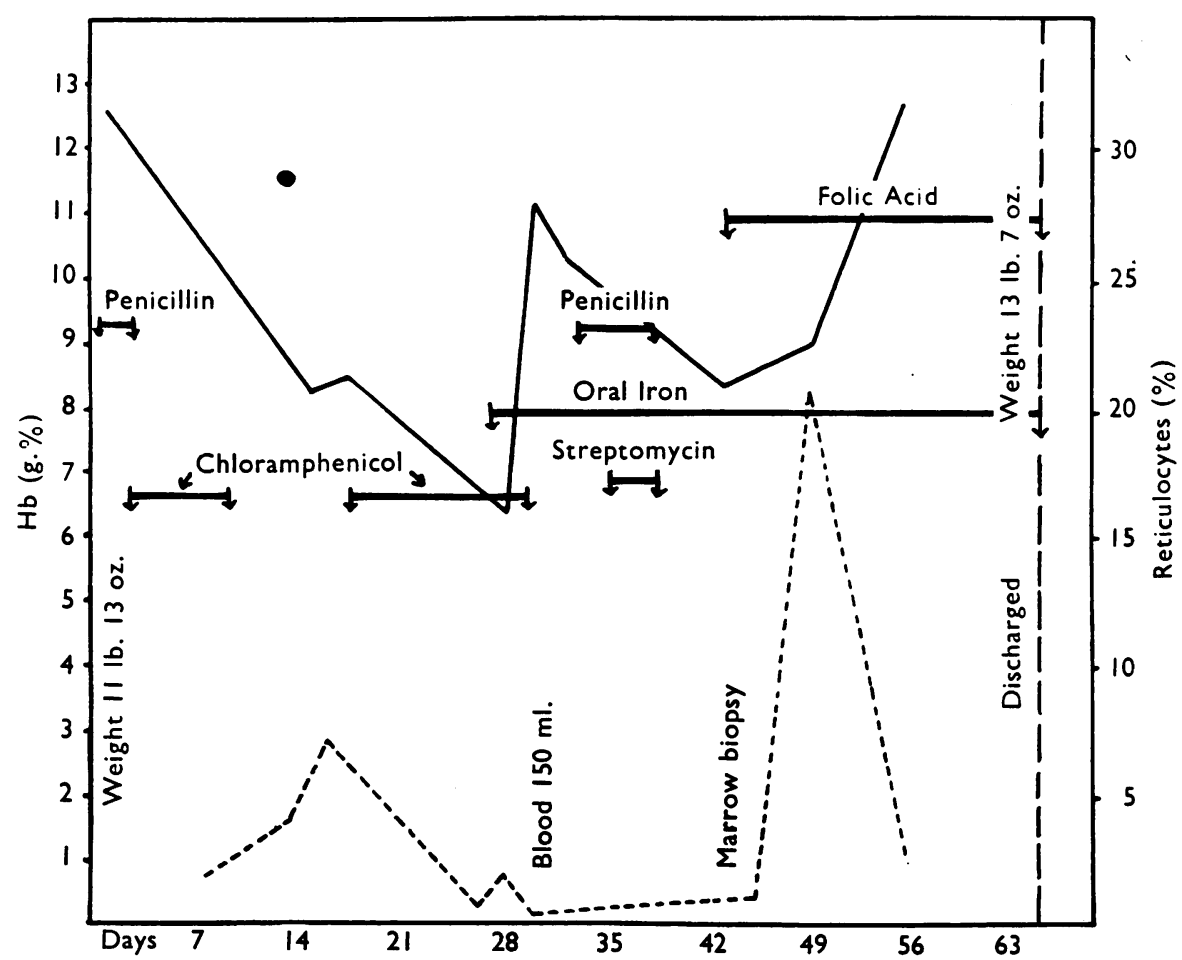

FIG. 9.-Chart of Case 9, aged 9 months, showing fall in haemoglobin level associated with $S$. typhimurium infection and response to folic acid. — Hb -... reticulocytes

TABLE 3

SUMMARY OF DIETARY HISTORIES

\begin{tabular}{|c|c|c|c|c|c|c|c|c|c|}
\hline $\begin{array}{l}\text { Case } \\
\text { No. }\end{array}$ & $\begin{array}{c}\text { Age } \\
\text { (mth.) }\end{array}$ & $\begin{array}{c}\text { Breast } \\
\text { Feeding } \\
\text { (mth.) }\end{array}$ & $\begin{array}{l}\text { Type of Milk } \\
\text { after Weaning }\end{array}$ & Cereals & Vegetables & Meat & Eggs & $\begin{array}{c}\text { Orange } \\
\text { Juice }\end{array}$ & Bush Teas \\
\hline 1 & 14 & 7 & Skim & Oats & $\begin{array}{l}\text { Cho-cho; } \\
\text { potatoes }\end{array}$ & - & Occasional & + & Mint \\
\hline 2 & 17 & 6 & Skim 2 mth.; & Cornmeal & - & - & - & 一 & - \\
\hline 3 & 11 & 3 & Condensed; goat's; & Oats & - & - & - & - & Love weed (dodder) \\
\hline 4 & 13 & 9 & $\begin{array}{l}\text { Cow's } 2 \text { mth. (none } \\
\text { subsequently) }\end{array}$ & - & - & Beef tea & - & - & - \\
\hline 5 & 10 & 9 & $\begin{array}{l}\text { Lactogen; Cow and } \\
\text { Gate }\end{array}$ & - & 一 & 一 & - & + & Love weed (dodder) \\
\hline 6 & 12 & 5 & Condensed & Oats & 一 & - & - & 一 & Mint; Irish-moss \\
\hline $\begin{array}{l}7 \\
8\end{array}$ & $\begin{array}{l}25 \\
10\end{array}$ & $\begin{array}{l}9 \\
2\end{array}$ & $\begin{array}{l}\text { Cow's } \\
\text { Lactogen; Ostermilk; } \\
\text { cow's }\end{array}$ & Cornmeal & Carrot juice & \pm & + & $\stackrel{+}{+}$ & $\begin{array}{l}\text { (sea-weed) } \\
\text { Mint }\end{array}$ \\
\hline $\begin{array}{r}9 \\
10\end{array}$ & $\begin{array}{l}9 \\
7\end{array}$ & $\begin{array}{l}7 \\
3\end{array}$ & Condensed; skim & $\begin{array}{l}\text { Oats; arrowroot } \\
\text { Barley water }\end{array}$ & Carrot juice & 二 & E & + & $\begin{array}{l}\text { Mint } \\
\text { Irish-moss (sea-weed) } \\
\text { linseed }\end{array}$ \\
\hline 11 & 12 & 3 & Skim & - & $\begin{array}{l}\text { Sweet potatoes; } \\
\text { carrot juice }\end{array}$ & - & 一 & - & linseed _ \\
\hline 12 & 12 & 6 & Condensed; occ. & Cornmeal & & Occasional & - & - & Mint \\
\hline 13 & 17 & 5 & $\begin{array}{l}\text { Condensed; occ. } \\
\text { cow's }\end{array}$ & Arrowroot & Occasional & - & Occasional & + & Rosemary; mint \\
\hline $\begin{array}{l}14 \\
15 \\
16\end{array}$ & $\begin{array}{l}20 \\
17 \\
11\end{array}$ & $\begin{array}{l}? \\
? \\
4\end{array}$ & Occ. goat's & - ? & $\stackrel{?}{-}$ & $\stackrel{-}{-}$ & $\stackrel{\bar{?}}{\text { Occasional }}$ & $\begin{array}{l}\bar{?} \\
+\end{array}$ & $\stackrel{?}{-}$ \\
\hline 17 & 12 & 2 & $\begin{array}{c}\text { Condensed; occ. } \\
\text { powdered }\end{array}$ & $\begin{array}{l}\text { Patent barley; } \\
\text { cornmeal; } \\
\text { Farex }\end{array}$ & - & - & - & - & - \\
\hline
\end{tabular}


TABLE 3-cont.

\begin{tabular}{|c|c|c|c|c|c|c|c|c|c|}
\hline $\begin{array}{r}\text { Case } \\
\text { No. }\end{array}$ & $\begin{array}{c}\text { Age } \\
(\mathrm{mth} .)\end{array}$ & $\begin{array}{c}\text { Breast } \\
\text { Feeding } \\
\text { (mth.) }\end{array}$ & $\begin{array}{l}\text { Type of Milk } \\
\text { after weaning }\end{array}$ & Cereals & Vegetables & Meat & Eggs & $\begin{array}{l}\text { Orange } \\
\text { Juice }\end{array}$ & Bush Teas \\
\hline 18 & 18 & 6 & Cow's; condensed & Occ. porridge & - & 一 & 一 & 一 & Jack-in-the-bush; \\
\hline $\begin{array}{l}19 \\
20\end{array}$ & $\begin{array}{r}9 \\
12\end{array}$ & $\begin{array}{l}5 \\
9\end{array}$ & $\begin{array}{l}\text { Cow's } \\
\text { Cow's; Ovaltine }\end{array}$ & $\begin{array}{l}\text { Farex } \\
\text { Wheat; corn- } \\
\text { meal }\end{array}$ & 二 & 二 & $\overline{-}$ & 二 & Various \\
\hline 21 & 17 & 9 & $\begin{array}{l}\text { Skim; condensed; } \\
\text { Cow and Gate }\end{array}$ & $\begin{array}{l}\text { Cornstarch; } \\
\text { barley }\end{array}$ & - & - & 一 & - & - \\
\hline 22 & 14 & 3 & Cow's; condensed & Cornmeal & 一 & - & 一 & - & $\begin{array}{l}\text { Cerosee; love weed } \\
\text { (dodder); Jack-in- } \\
\text { the-bush }\end{array}$ \\
\hline $\begin{array}{l}23 \\
24 \\
25\end{array}$ & $\begin{array}{l}13 \\
18 \\
12\end{array}$ & $\begin{array}{r}12 \\
3 \\
8\end{array}$ & $\begin{array}{l}\text { Lactogen } \\
\text { Lactogen } \\
\text { Condensed; Ovaltine; } \\
\text { skim }\end{array}$ & $\begin{array}{l}\text { Saltine biscuits } \\
\text { Porridge } \\
\text { Quaker oats }\end{array}$ & $\frac{\bar{Z}}{\text { Sweet potatoes }}$ & 二 & $\frac{ \pm}{\text { Occasional }}$ & \pm & $\begin{array}{l}\text { Various } \\
\text { Mint; cerosee }\end{array}$ \\
\hline $\begin{array}{l}26 \\
27\end{array}$ & $\begin{array}{l}17 \\
10\end{array}$ & 5 & $\begin{array}{l}\text { Lactogen; cow's } \\
\text { Skim; goat's since } \\
5 \text { mth. }\end{array}$ & $\begin{array}{l}\text { Cornmeal } \\
\text { Oats }\end{array}$ & Sweet potatoes & 二 & 二 & 二 & Mint \\
\hline $\begin{array}{l}28 \\
29\end{array}$ & $\begin{array}{r}15 \\
8\end{array}$ & $\begin{array}{l}4 \\
6\end{array}$ & $\begin{array}{l}\text { Cow's; Milo } \\
\text { Cow and Gate; } \\
\text { Ostermilk; } \\
\text { condensed }\end{array}$ & Oats & Sweet potatoes & 二 & + & + & $\begin{array}{l}\text { Irish-moss (sea-weed); } \\
\text { linseed }\end{array}$ \\
\hline 30 & 9 & 3 & $\begin{array}{l}\text { None } 1 \text { mth.; cow's } \\
3 \text { mth.; none last } \\
2 \text { mth. }\end{array}$ & $\begin{array}{l}\text { Cornmeal; } \\
\text { barley; } \\
\text { cornstarch; } \\
\text { arrowroot }\end{array}$ & 一 & - & - & $*+$ & - \\
\hline 31 & 14 & 7 & Skim & Oats & - & - & - & + & $\begin{array}{l}\text { Mint; Jack-in-the- } \\
\text { bush }\end{array}$ \\
\hline $\begin{array}{l}32 \\
33\end{array}$ & 21 & $\begin{array}{l}9 \\
8\end{array}$ & $\begin{array}{l}\text { Condensed } \\
\text { Cow's }\end{array}$ & $\begin{array}{l}\text { Porridge } \\
\text { Wheat; rice }\end{array}$ & $\begin{array}{l}\text { Banana } \\
\text { Yam; sweet } \\
\text { potatoes }\end{array}$ & $\begin{array}{l}\text { Fish tea } \\
\text { Fish }\end{array}$ & $\overline{+}$ & $\bar{t}$ & 二 \\
\hline 34 & 8 & $t$ & $\begin{array}{l}\text { None } 2 \text { mth.; skim; } \\
\text { cow's; condensed }\end{array}$ & Oats at $3 \mathrm{mth}$. & polatues & - & 一 & $\begin{array}{l}\text { Occa- } \\
\text { sional }\end{array}$ & Mint \\
\hline $\begin{array}{l}35 \\
36\end{array}$ & $\begin{array}{l}10 \\
15\end{array}$ & $\begin{array}{l}6 \\
6\end{array}$ & $\begin{array}{l}\text { Skim } \\
\text { Cow's; Lactogen; }\end{array}$ & $\begin{array}{l}\text { Barley; oats } \\
\text { Barley; Bemax }\end{array}$ & 二 & Fish tea & 二 & 二 & Mint \\
\hline 37 & 11 & 6 & $\begin{array}{l}\text { Ovaltine; Milo; } \\
\text { condensed }\end{array}$ & $\begin{array}{l}\text { Oats; cornmeal; } \\
\text { arrowroot }\end{array}$ & - & 一 & + & + & Mint \\
\hline 38 & 9 & $\frac{3}{4}$ & $\begin{array}{l}\text { Various proprietary } \\
\text { brands; none from } \\
4 \mathrm{mth} \text {. }\end{array}$ & Cornmeal & Green banana & - & - & - & - \\
\hline 39 & 18 & 4 & Lactogen; Ovaltine & $\begin{array}{r}\text { Barley } \\
\text { oats }\end{array}\left\{\begin{array}{l}\text { from } \\
1 \text { yr. }\end{array}\right.$ & 一 & 一 & 一 & - & $\begin{array}{l}\text { Cotton; } \\
\text { mint; Irish-mors } \\
\text { (sea-weed) }\end{array}$ \\
\hline 40 & 12 & 6 & $\begin{array}{l}\text { Lactogen; Horlicks; } \\
\text { condensed }\end{array}$ & Cornmeal & Coconut milk & - & - & - & $\begin{array}{l}\text { Milk-weed; negeu; } \\
\text { vervine; love-bush; } \\
\text { Jack-in-the-bush }\end{array}$ \\
\hline 41 & 37 & $?$ & 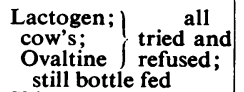 & $\begin{array}{c}\text { Barley water; } \\
\text { porridge }\end{array}$ & $\begin{array}{l}\text { Tried and } \\
\text { refused }\end{array}$ & $\begin{array}{c}\text { Tried and } \\
\text { refused }\end{array}$ & $\begin{array}{l}\text { Tried and } \\
\text { refused }\end{array}$ & $\begin{array}{c}\text { Tried } \\
\text { and } \\
\text { refused }\end{array}$ & Jack-1n-tne-dusn \\
\hline 42 & 13 & - & $\begin{array}{l}\text { Skim; condensed; } \\
\text { Vita-cup }\end{array}$ & 一 & - & 一 & 一 & - & - \\
\hline 43 & 12 & - & $\begin{array}{l}\text { Horlicks; Cow and } \\
\text { Gate; skim; goat's }\end{array}$ & 一 & - & - & - & - & $\begin{array}{l}\text { Jack-in-the-bush; } \\
\text { White Joseph's } \\
\text { coat; God bush; } \\
\text { mint }\end{array}$ \\
\hline $44^{*}$ & 11 & ? & $\begin{array}{l}\text { Condensed; little or } \\
\text { none for } 3 \mathrm{mth} \text {. }\end{array}$ & Oats; cornmeal & 一 & - & 一 & 一 & - \\
\hline $\begin{array}{l}45 \\
46\end{array}$ & $\begin{array}{l}16 \\
13\end{array}$ & $\begin{array}{r}10 \\
8\end{array}$ & $\begin{array}{l}\text { Cow's; Lactogen } \\
\text { Lactogen; con- } \\
\text { densed; skim }\end{array}$ & $\begin{array}{l}\text { Oats } \\
\text { Oats }\end{array}$ & - & 二 & 二 & 二 & Mint; cerosee \\
\hline 47 & 12 & 5 & Condensed; skim & Barley water & $\begin{array}{l}\text { Spinach; sweet } \\
\text { potatoes; } \\
\text { cho-cho }\end{array}$ & - & - & - & Mint \\
\hline 48 & 14 & 8 & $\begin{array}{l}\text { Ostermilk; Milo; } \\
\text { condensed }\end{array}$ & Bread; biscuit & Sweet potatoes & $\begin{array}{l}\text { Soup, } \\
\text { fish tea }\end{array}$ & + & - & 一 \\
\hline $\begin{array}{l}49 \\
50\end{array}$ & $\begin{array}{l}12 \\
15\end{array}$ & $\begin{array}{l}7 \\
8\end{array}$ & $\begin{array}{l}\text { Cow's; Milo } \\
\text { Lactogen; Cow and } \\
\text { Gate }\end{array}$ & $\begin{array}{l}\text { Oats; sago } \\
\text { Barley }\end{array}$ & Carrot juice & $\begin{array}{l}\text { Fish tea } \\
\text { Fish tea }\end{array}$ & $\bar{t}$ & 二 & Mint \\
\hline
\end{tabular}

* 3-day dietary survey at home showed intake of 400 calories and $0.75 \mathrm{~g}$. protein per day

quantities of condensed or powdered milk. Goat's milk, which has an even lower folic acid content than human or cow's milk (May et al., 1952), was included in the diet of four infants in this series (Cases 3, 14, 27 and 43). Supplementary foods rich in folic acid, such as meat and green vegetables, were almost totally absent from their diets, which con- sisted largely of cereals, such as cornmeal, made into a porridge with small quantities of milk, supplemented with a variable quantity of carbohydrate-rich foods such as sweet potato, green banana, cassava and yam. The folic acid content of these foods is not known, but, with the possible exception of green bananas, it is not likely to be high. Vitamin $\mathbf{B}_{12}$ 
is found in most animal tissues such as meat and eggs, but it is almost completely absent from higher plants. Milk contains a reasonable amount of vitamin $B_{12}$ but the quantity given to these infants was generally very small, one or two tins of condensed milk being required to last a week or more in most cases. It is therefore quite probable that the children were deficient in both folic acid and vitamin $B_{12}$, although it seems likely that deficiency of folic acid is the most important factor. In addition to the inadequate intake of haemopoietic substances, the children also received too little protein, and the results of protein malnutrition became manifest. Anorexia was usual and vomiting and diarrhoea were frequent so that the already small intake of haemopoietic substances was further reduced and absorption was impaired.

It is probable that the disease could be quickly eradicated in Jamaica if supplies of milk were more freely available and in particular if the mothers were educated to the importance of including some green vegetables and, if economically possible, meat in the diets of their children in the post-weaning period.

\section{Summary}

The literature on megaloblastic anaemia of infancy is briefly reviewed with particular reference to its occurrence in association with protein malnutrition (kwashiorkor).

The clinical, haematological and other laboratory findings in 50 cases of megaloblastic anaemia of infancy are presented. From a clinical point of view the most striking feature is that almost all the infants were very malnourished and grossly underweight. The bone marrow morphology is described, and the diagnostic value of specific changes in the granulocytic series is stressed.

An interesting pathological finding was the presence of extramedullary erythropoiesis in the liver. This was found at necropsy in three out of six cases, and on liver biopsy in seven out of 10 cases. Although not constantly present, extramedullary erythropoiesis is thought to be pathognomonic of the disease.

Of the 50 cases in the series 45 were given folic acid and five received vitamin $B_{12}$. Six of the folic acid treated cases died. The response to both folic acid and vitamin $B_{12}$ in the remaining cases was excellent. No response to antibiotics was noted. The pathogenesis of the disease is discussed in some detail and illustrated with cases. Although there is no doubt of the importance of ascorbic acid deficiency and of infection in the aetiology of megaloblastic anaemia of infancy, it seems probable that a dietary deficiency of essential haemopoietic factors is the major cause.
Whether the main deficiency is of folic acid or of vitamin $B_{12}$ is uncertain at the present time, although in our view a deficiency of folic acid seems likely to be the more important.

The authors are greatly indebted to Dr. J. C. Waterlow, Director of the Medical Research Council's Tropical Metabolism Research Unit, for his permission to include 14 cases which were under his care. They are also very grateful to Professor G. Bras for his advice and assistance with the histology of the liver.

\section{REFERENCES}

Adams, E. B. (1954). Brit. med. J., 1, 537

Aldrich, R. A and Nelson, E. N. (1947). J.-Lancet, 67, 399

Altmann, A. and Murray, J. F. (1948). S. Afr. J. med. Sci., 13, 91.

Amato, M. (1946). Pediatria (Napoli), 54, 71 .

and di Gruttola, G. (1956). Ibid., 64, 1 .

Bras, G., Waterlow, J. C. and DePass, E. (1956). J. trop. Pediat., $2,147$.

Dacie, J. V. and White, J. C. (1949). J. clin. Path., 2, 1.

Daland, G. A. and Castle, W. B. (1948). J. Lab. clin. Med., 33, 1082.

Davidson, W. M. (1952). Lancet, 1, 566.

Downey, H. (1952) J. Lab. clin. Med., $39,837$.

Elizavéta, T. O. (1955). Čsi. Pediat., 10, 622.

Foy, H., Kondi, A. and Manson-Bahr, P. E. C. (1955). Lancet, 2, 693.

Frazer, A. C. (1958). Personal communication.

Freire, L. C. (1954). Gaz. méd. port., 7, 115.

Gatto, I. (1957). Blut, 3, 31.

Gerbasi, M. and Burgio, G. R. (1955). Sci. med. ital., 4, 49.

Gerbasi, . Santaella, J. V., Galván, R. R., Cravioto, J. and Frenk, S. (1954). A.M.A. Amer. J. Dis. Child., 87, 673.

Jelliffe, D. B., Bras, G. and Stuart, K. L. (1954). W. Indian med. J., 3, 43.

Kho Lien-Keng, Soddjono, D. Poesponegoro and Poey Seng Hin (1957). Docum. Med. geogr. trop. (Amst.), 9, 69.

Lambrecht, A. and Holemans, K. (1952). Ann. Soc. belge Méd. trop., 32,657 .

Lehmann, H. (1955). Trans. roy. Soc. trop. Med. Myg., 49, 90.

Luhby, A. L. and Wheeler, W. E. (1949). Health Center J. Ohio State Univ., 3,1 .

MacIver, J. E. and Went, L. N. (1960). Brit. med. J., 1, 775.

McPherson, A. Z., Jonsson, U. and Rundles, R. W. (1949). J. Pediat., 34, 529 .

May, C. D., Hamilton, A. and Stewart, C. T. (1953). J. Nutr., 49, 121. Nelson, E. N.. Lowe, C. U. and Salmon, R. J. (1950). Amer.

J. Dis. Child., 80, 191. J. (1949). J. Lab. clin. Med., 34, 1724

, Stewart, C. T., Hamilton, A. and Salmon, R. J. (1952). A.M.A. Amer. J. Dis. CChildh., 84, 718.

Sundberg, R. D. and Schaar, F. (1950). J. Lab. clin. Med., 36, 963.

Amer. J. Dis. Child., 82, 282

Mertens, E. (1945). Amer.J. med. Sci., 210, 630.

Morice, J., Gurzmán, E. and Costa, A. (1955). Arch. Hosp. Clin. Ninos., R. del Rio, 22, 34.

Mouriquand, C. (1954). Pédiatrie, 9, 485

Nelson, M. G. and Creery, R. D. G. (1955). Irish J. med. Sci., 6, 73.

Nelson, W. E. (1950). Mitchell-Nelson Textbook of Pediatrics, 5th ed., Saunders, Philadelphia.

Netrasiri, A. and Netrasiri, C. (1955). J. trop. Pediat., 1, 148.

Pecorella, F., Burgio, G. R. and Aversa, T. (1947). Riv. Clin. pediat., 45,65 .

Poey Seng Hin (1957). M.D. Thesis. University of Indonesia.

Sar, A. van der (1951). Docum. neerl. indones. Morb. trop., 3, 25.

Sturgeon, P. and Carpenter, G. (1950). Blood, 5, 458.

Sundberg, R. D. Schaar, F. and May, C. D. (1952). Ibid., 7, 1143.

Trowell, H. C. (1949). Trans. roy. Soc. trop. Med. Hyg., 42, 417.

Trow and Davies, J. N. P. (1952). Brit. med. J., 2, 798.

Arnold, London.

Walt, F., Holman, S. and Hendrickse, R. G. (1956). Brit. med. J., 1, 1199 .

-, Wills, L. and Nightingale, R. P. (1950). S. Afr. med. J., 24, 920

Whitby, L. E. H. and Britton, C. J. C. (1957). Disorders of the Blood, 8 th ed. Churchill, London.

Woodruff, A. W. (1955). Brit. med. J., 1, 1297.

Zuelzer, W. W. and Ogden, F. N. (1946). Amer. J. Dis. Child., 71, 211.

and Rutzky, J. (1953). In Advanc. Pediat., 6, 243. 